\title{
Composition of bronchopulmonary secretions from patients with bronchiectasis
}

\author{
T D BROGAN, B H DAVIES, H C RYLEY, P J ROSS, AND L NEALE \\ From the Asthma Research Unit, Sully Hospital, Sully, and Department of Microbiology, \\ Welsh National School of Medicine, Cardiff, South Glamorgan
}

ABSTRACT Pulmonary function tests were carried out on 17 patients with bronchiectasis and sid indices were selected to grade severity. Average concentrations of nine plasma proteins wer: determined by quantitative immunoelectrophoresis in specimens of sputum and serum from each patient. Wide patient-to-patient variation in concentration was encountered which appeared to follow a continuous progression unrelated to clinical severity. Patients at the upper end of the scale appeared to be responding by exudation and a pulmonary hypersensitivity reaction may be occurring in their lungs. There was evidence of selective concentration in sputum of $\alpha 1$-antichymor trypsin and IgA although IgA concentrations were lower than would be expected in patients wit chronic bronchitis. It is suggested that sputum IgA levels could be explored as a diagnostic criterio $\vec{P}$ in those patients who could equally be suffering from chronic bronchitis.

Bronchiectasis is a histopathological description of an alteration in the architecture of the bronchi and the development of symptoms is related to the onset of infection. ${ }^{1}$ Before the advent of antibiotic therapy, patients with bronchiectasis tended to produce copious quantities of foul and foetid sputum. However, improvements in oral hygiene and the ready availability of antimicrobial drugs has changed this picture. Symptoms of dyspnoea and wheeze are frequent in bronchiectasis and have been related to the development of chronic bronchitis.

The composition of the ground substance of the sputum has been found by us to be related to the diagnosis in some chest diseases. ${ }^{2}{ }^{3}$ In the present investigation we examined the soluble proteins of sputum specimens from a series of patients with clinically proven bronchiectasis to see whether the composition of the sol or continuous phase of sputum can be a guide to the existence of bronchiectasis or the development of chronic bronchitis, or if it can be related to the severity of the disease.

\section{Methods}

Seventeen patients (nine women and eight men, average age $45 \pm 12$ years) with a clinical diagnosis of bronchiectasis were admitted to Sully

Address for reprint requests: Dr BH Davies, Asthma Research Unit, Sully Hospital, Sully, Penarth, South Glamorgan.
Hospital for investigation.

A clinical questionnaire was completed on a patients noting age of onset of symptoms, coug frequency and nature of sputum, haemoptysis dyspnoea, and systemic symptoms such as weight loss and malaise. A past history of severe respiras tory infection in early childhood was noted specifically and the patient's smoking habits were documented. Clinical examination by a single observer evaluated the presence or absence oD clubbing, cyanosis, anaemia, pulmonary crackles and right ventricular hypertrophy. Bronchograms had been carried out on 14 of the patients. the remaining three had radiographic changes compatible with bronchiectasis. Radiographie classification was performed by the method of Simon, ${ }^{4}$ and the severity assessed on the basis of the number of lobes involved; all films wer assessed by one observer.

The forced expiratory volume in one secon® $\left(F_{1} V_{1}\right)$ and forced vital capacity (FVC) werE measured with an eight litre McDermott spirow meter. All values were compared to the predicted normal values of Cotes. ${ }^{5}$

A 24-hour collection of sputum was carrie $\$$ out on each of the patients. All specimens were? processed immediately after collection ando weighed aliquots of sputum were centrifuged ap $120000 \mathrm{~g}$ (average rotor radius $=8.5 \mathrm{~cm}$ ) using the SW50 rotor in a model L2 spinco ultracentri ${ }_{0}{ }_{0}$ fuge (Beckman Instruments, California, USA) fot: 
three and a half hours at $4^{\circ} \mathrm{C}$. Quantitative immunoelectrophoresis of the soluble proteins in the sputum sol phase was carried out substantially by the same methods as those described in detail elsewhere. ${ }^{6}$ The concentration of the plasma proteins in the specimens of serum from each patient was measured by the techniques employed for determining the concentration of the corresponding proteins in the sol phase of sputum.

\section{Results}

\section{CLINICAL ASSESSMENT}

Patients were graded on a simple score on the basis of six indices chosen because they appeared to provide the best basis of discrimination between the individual patients studied. The indices were: the onset of symptoms before the age of 5 years; the presence or absence of dyspnoea when walking quietly on level ground; the presence of pulmonary crackles; the radiological involvement of four or more lobes (for this purpose the lingula was considered as a separate lobe); the presence of airways obstruction, $\left(\mathrm{FEV}_{1} / \mathrm{FEV}\right.$ ratio less than $\left.60 \%\right)$ and a history of cigarette smoking. The results of the clinical grading are summarised in table 1 . It can be seen that 10 of the patients had relatively mild bronchiectasis (grades 0,1 , or 2) and the remainder had moderately severe or severe bronchiectasis (grades 3, 4, or 5).

\section{IMMUNOCHEMISTRY}

Wide variation was encountered when the concentrations of plasma proteins in the sol phase of sputum were measured (table 2). Patient-to- patient variation in sputum sol phase albumin concentrations appeared to follow a progressive type of pattern that was unrelated to clinical grading (fig 1). All other plasma protein concentrations, with the exception of $\operatorname{IgA}(r=0.46$, $0.05<\mathrm{p}<0.1)$ showed significant correlation with the sputum sol phase albumin concentrations. The concentration ratios of albumin in matched specimens of serum and sputum were inversely related to the sputum sol phase albumin concentrations $(\mathrm{r}=0.95, \mathrm{p}<0.0001)$, and all other protein concentration ratios correlated significantly with the albumin concentration ratio except IgA $(r=0.29), \alpha_{1}$-antichymotrypsin $(r=$ $0.24)$, and $C 3(r=0.25)$; the probabilities in each case were $0.2<\mathrm{p}<0.5$. The mean concentrations of $\operatorname{IgA}$ relative to transferin matched pairs of sputum and serum were $9.51 \pm 6.03$ and $1.49 \pm 0.63(t=5.29,<0.0001)$ and those of $\alpha_{1}$. antichymotrypsin in sputum and serum were $4.45 \pm 3.19$ and $1.73 \pm 1.42(t=3.11 ; 0.0001<\mathrm{p}$ $<0.0005)$ thus suggesting selective concentration in sputum of these two plasma proteins. In contrast, the corresponding relative concentrations of $\mathrm{C} 3$ in sputum and serum were $3.52 \pm$ 1.43 and $2.37 \pm 0.78$ and these differences only just achieved significance $(0.025<\mathrm{p}<0.05)$.

\section{Discussion}

The patient-to-patient variation in the concentrations of the plasma proteins in the sol phase of the sputum specimens seemed to follow a continuous progression. Although some patients appear to produce sputum resembling that of patients with chronic bronchitis, others at the

Table 1 Clinical grading of patients with bronchiectasis

\begin{tabular}{|c|c|c|c|c|c|c|c|}
\hline \multirow{2}{*}{ Patient number } & \multicolumn{6}{|l|}{ Indices } & \multirow[t]{2}{*}{ Score } \\
\hline & $\begin{array}{l}\text { Onset of symptoms } \\
\text { at age } 5 \text { years }\end{array}$ & Dyspnoea & $\begin{array}{l}\text { Pulmonary } \\
\text { crackles }\end{array}$ & $\begin{array}{l}\text { Radiographic evidence } \\
\text { of involvement of } \\
\text { four lobes }\end{array}$ & $\begin{array}{l}\text { Ratio } \\
F E V_{1} / F V C \\
>60 \%\end{array}$ & $\begin{array}{l}\text { Cigarette } \\
\text { smoking }\end{array}$ & \\
\hline 1 & - & - & - & - & - & - & 0 \\
\hline 2 & + & + & + & + & + & - & 5 \\
\hline 3 & - & - & - & + & NT & + & 2 \\
\hline 4 & + & + & + & + & + & - & 5 \\
\hline 5 & + & - & + & - & + & $\ldots$ & 3 \\
\hline 6 & - & - & - & - & - & - & 0 \\
\hline 7 & - & - & + & - & - & + & 2 \\
\hline 8 & - & - & - & - & NT & - & 0 \\
\hline 9 & - & - & - & - & - & + & 1 \\
\hline 10 & + & + & + & + & + & - & 5 \\
\hline 11 & - & - & - & - & - & + & 1 \\
\hline 12 & - & - & - & - & - & + & 1 \\
\hline 13 & + & - & - & - &. & - & 1 \\
\hline 14 & + & + & + & + & + & - & 5 \\
\hline 15 & - & + & + & - & - & + & 3 \\
\hline 16 & - & - & - & - & - & - & 0 \\
\hline 17 & + & - & + & + & + & - & 4 \\
\hline
\end{tabular}

NT-not tested 
Table 2 Average concentrations of nine plasma proteins in the sol phase of sputum and in matched serum specimens from 17 patients with bronchiectasis

\begin{tabular}{|c|c|c|c|c|c|c|}
\hline \multirow[t]{2}{*}{ Plasma proteins } & \multicolumn{2}{|c|}{$\begin{array}{l}\text { Serum concentration } \\
(\mathrm{mg} / 100 \mathrm{ml})\end{array}$} & \multicolumn{2}{|c|}{$\begin{array}{l}\text { Sputum concentration } \\
\text { ( } \mathrm{mg} / 100 \mathrm{ml} \text { sol phase) }\end{array}$} & \multicolumn{2}{|c|}{$\begin{array}{l}\text { Protein concentration } \\
\text { ratios }: \text { serum/sputum }\end{array}$} \\
\hline & Average & $\begin{array}{l}\text { Limits of } \\
\text { determined } \\
\text { values }\end{array}$ & Average & $\begin{array}{l}\text { Limits of } \\
\text { determined } \\
\text { values }\end{array}$ & Average & $\begin{array}{l}\text { Limits of } \\
\text { calculated } \\
\text { values }\end{array}$ \\
\hline $\begin{array}{l}\text { Albumin } \\
\text { Transferin } \\
\alpha_{1} \text {-acid glycoprotein } \\
\text { Haptoglobin } \\
\alpha_{1} \text {-antitrypsin } \\
\alpha_{1} \text {-antichymotrypsin } \\
B_{1} \text {-c globulin (C3) } \\
\text { IgA } \\
\text { IgG }\end{array}$ & $\begin{array}{r}4536 \\
229 \\
179 \\
343 \\
224 \\
36 \\
52 \\
337 \\
1416\end{array}$ & $\begin{array}{c}3000-6250 \\
140-410 \\
62-420 \\
124-690 \\
110-560 \\
10-98 \\
30-75 \\
170-840 \\
470-2277\end{array}$ & $\begin{array}{r}87 \cdot 5 \\
6 \cdot 5 \\
2 \cdot 5 \\
4 \cdot 7 \\
13 \cdot 5 \\
2 \cdot 5 \\
2 \cdot 3 \\
42 \cdot 7 \\
35 \cdot 3\end{array}$ & $\begin{array}{l}12-320 \\
1 \cdot 2-15 \cdot 6 \\
0 \cdot 3-5 \cdot 6 \\
0 \cdot 3-17 \cdot 5 \\
0 \cdot 7-48 \cdot 0 \\
0 \cdot 2-10 \cdot 0 \\
0 \cdot 6-5 \cdot 6 \\
6 \cdot 5-95 \\
5 \cdot 4-91\end{array}$ & $\begin{array}{r}122 \\
68 \\
121 \\
284 \\
60 \\
26 \\
40 \\
13 \\
78\end{array}$ & $\begin{array}{r}335-13 \\
160-15 \\
309-20 \\
783-23 \\
188-5 \cdot 5 \\
150-5 \cdot 5 \\
75-8 \cdot 9 \\
29-3 \cdot 6 \\
380-3 \cdot 4\end{array}$ \\
\hline
\end{tabular}

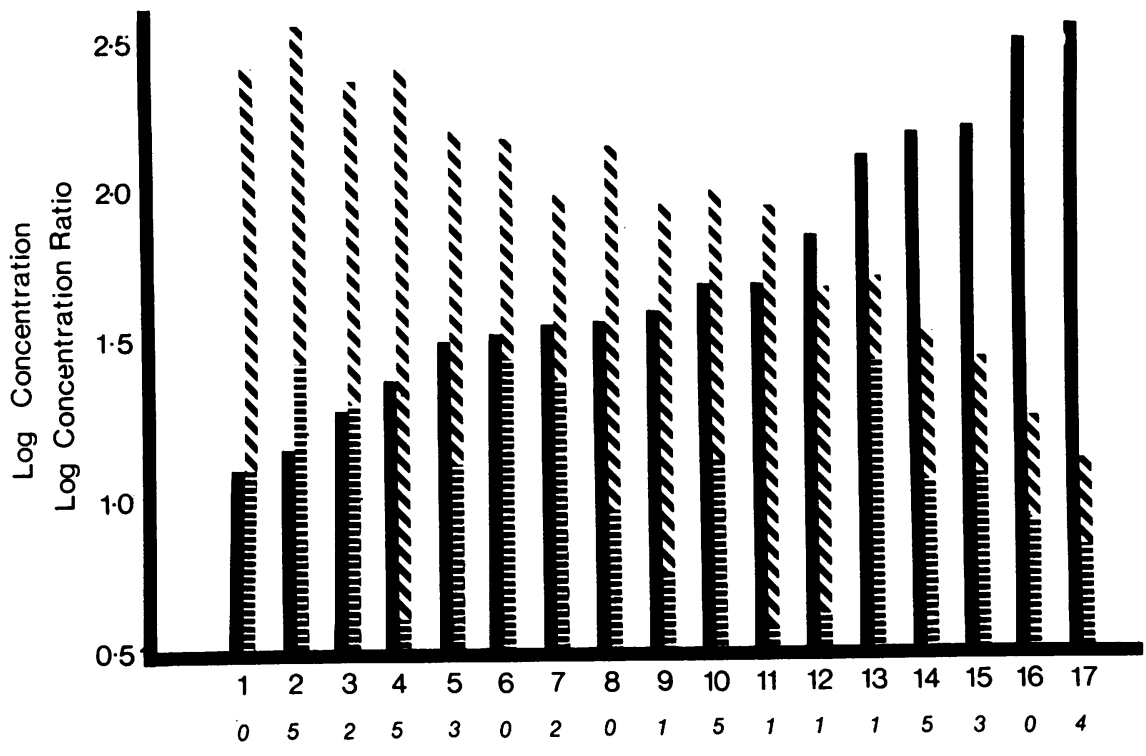

Patient Number

Clinical Grading

Figure Variation in sputum sol phase albumin concentrations in individual bronchiectasis patients whose clinical grading has been determined, compared with serum: sputum albumin concentration ratios showing inverse correlation of the values. The IgA concentration ratios in matched serum :sputum specimens are also illustrated to show lack of correlation with the corresponding albumin concentration ratios.

$\mathbf{0}=$ Sol phase albumin concentrations, $\mathbb{N}=$ serum:sputum albumin concentration ratios, 目= serum :sputum $\operatorname{Ig} A$ concentration ratios.

upper end of the "scale" have high plasma protein concentrations in the sol phase of their sputum, which is similar to that of patients with status asthmaticus. ${ }^{3}$ It is thus possible that a pulmonary hypersensitivity reaction, in the broadest sense of the term, may cause the exudative character of the sputum in a proportion of patients with bronchiectasis. It is of interest that our similar findings in patients with cystic fibrosis ${ }^{3}$ could have been caused by the lung damage that characterises this disease and which amounts virtually to bronchiectasis.

Forty per cent of the patients in this studg suffered severe bronchiectasis as defined by the indices we describe, but the pulmonary function tests were entirely unrelated to the sputum immunochemistry. There was some evidence suggesting selective concentration of two plasma 
proteins ( $\alpha_{1}$-antichymotrypsin and $\left.\lg \mathrm{A}\right)$ in the sol phase of the patients' sputum and this has been noted by us in other chronic chest diseases. However, the average concentration of $\operatorname{IgA}$ in the sputum of patients with bronchiectasis was lower than that of sputum from patients with bronchitis. $^{3}$ i This finding may be worth exploring as a means of providing additional evidence in support of the diagnosis of bronchiectasis in those patients who could equally be suffering from chronic bronchitis.

\section{References}

1 Crofton J, Douglas A. Respiratory diseases. Second edition. Oxford: Blackwell Scientific
Publications, 1975.

2 Brogan TD, Ryley HC, Allen L, Hutt H. Relation between sputum sol phase composition and diagnosis in chronic chest diseases. Thorax 1971; 26: 418-23.

3 Brogan TD, Ryley HC, Neal L, Yassa J. Soluble proteins of bronchopulmonary secretions from patients with cystic fibrosis, asthma, and bronchitis. Thorax 1975; 30:72-9.

4 Simon G. Principles of chest $x$-ray diagnosis. Third edition. London: Butterworth, 1971.

5 Cotes JE. Lung function. Third edition. Oxford: Blackwell Scientific Publications, 1975.

6 Ryley HC, Brogan TD. Quantitative immunoelectrophoretic analysis of the plasma proteins in the sol phase of sputum on patients with chronic bronchitis. J Clin Pathol 1973; 26:852-6. 